DOI: https://doi.org/10.31933/dijemss.v2i5

Received: 30 May 2021, Revised: 30 June 2021, Publish: 31 July 2021

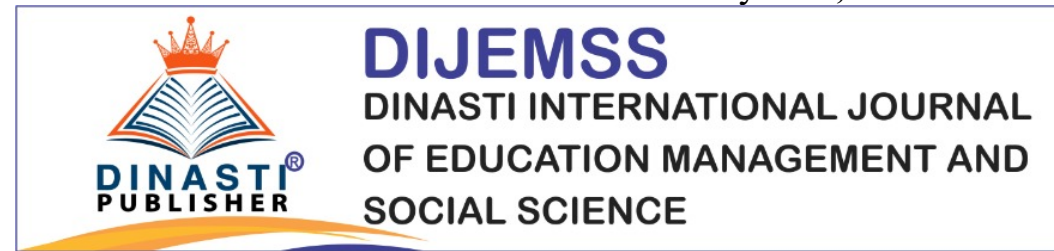

https://dinastipub.org/DIJEMSS \& editor@dinastipub.org 08117401455 (C)

\title{
EXPANDED THE PRODUCTION EFFECTIVENESS THROUGH PRODUCTION PLANNING, RAW MATERIAL CONTROL, SCHEDULE CONTROL AND PRODUCTION CONTROL AT PT. LPA
}

\author{
Afthon Kumbara ${ }^{1}$, Agustinus Hariadi DP ${ }^{2}$ \\ 1) Mercu Buana University, Jakarta, Indonesia, afthonkumbara123@gmail.com \\ 2) Mercu Buana University, Jakarta, Indonesia, agustinus.hariadi@mercubuana.ac.id
}

\section{Corresponding Author: Afthon Kumbara}

\begin{abstract}
PT. LPA is one of textile manufacturing company who is still doing the production process by woven fabrics (Weaving) and finishing fabrics (Printing, Dyeing and White). The problems that are often faced by PT. LPA is the completion time of production which is still not according to the targets that have been planned, then the production effectiveness would not be achieved so with the suitability of orders or quality which has not been met with expectation. This research aims to find out the impact of production planning on raw material control, schedule control and production control as well as the impact from raw material control to production effectiveness, schedule control affect on production effectiveness and production control affect on production effectiveness. Questionnaire data analysis which involves 65 respondents, those employees from PT. LPA then the data would be processed through validity and reliability test using the PLS-SEM analysis method. So the results that obtained from this research were production planning had a positive and significant impact on raw material control, production planning had a positive and significant impact on schedule control, production planning had a positive and significant impact on production control, raw material control had a positive and significant impact on production effectiveness, schedule control had a positive and significant impact on production effectiveness, production control had a positive and significant impact on production effectiveness.
\end{abstract}

Keywords: Planning, Production, Effectiveness, Control, PLS-SEM.

\section{INTRODUCTION}

PT. LPA is one of a companies which engaged in the textile industry and was included in one of the subsidiaries of LTG. LTG has 2 subsidiaries, which are PT. BCI and PT. LPA. These companies have different production results but are still mutually sustainable. PT. BCI produces yarn products with main raw material, namely cotton, while PT. LPA produces woven fabrics (Weaving) and finishing fabrics (Printing, Dyeing and White). The raw materials used in the manufacture of woven fabrics (Weaving) are yarns from PT. BCI or 
purchase yarn from outside factories according to the type of raw material needed. While the process of finishing fabrics (Printing, Dyeing and White) the raw materials used are woven fabrics (Weaving) which are derived from the weaving production process at PT. LPA, purchase of fabric (Purchase Greige) and fabric provided by the customer (makloon fabric).

The problems faced by PT. LPA is accomplishment time of production, which is not according to the planned target, causing production effectiveness could not be achieved as it shown in Figure 1.1 Regarding effectiveness. Based on Gaspersz (2012), it is said that effectiveness is another characteristic of the process which could assess from the level of achievement of the production system output. Željko Mateljak \& Damir Mihanović (2016) mentioned in their research that the production effectiveness process will depend on the level of development of operational planning and implies the ability of the production company to realize the goals set. That Effectiveness could be deliberate based on the ratio of the actual output to the planned output (target) of the product order.

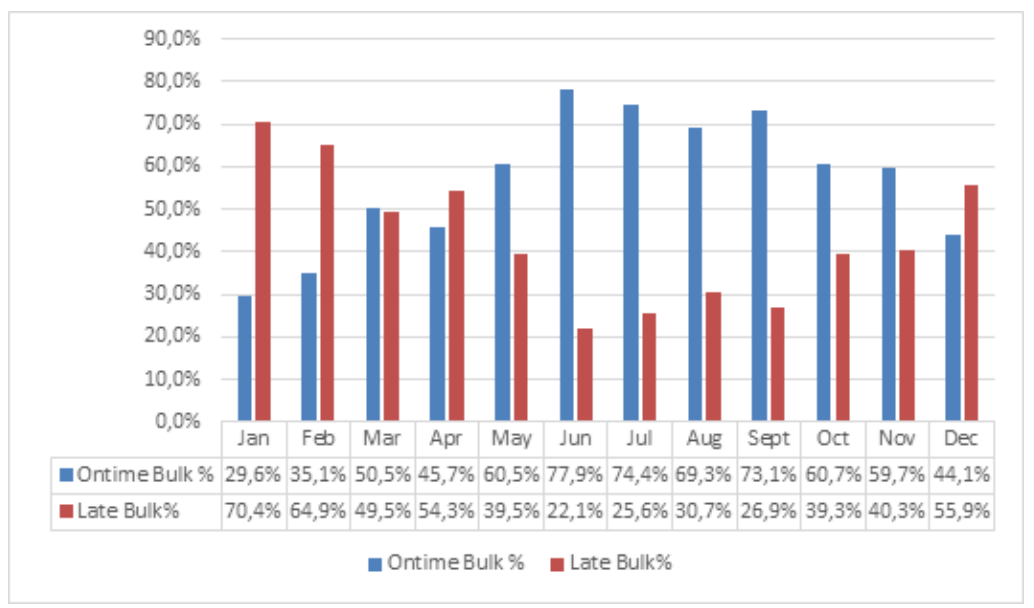

Figure 1. Ontime and Late Finish Productions 2019

It is known that the total finish productions for LPA fabrics in 2019 are 10,999,430.1 $\mathrm{m}$, while the total finish productions for Makloon fabrics in 2019 are 7,181,792.6 $\mathrm{m}$ so the total finish productions in 2019 was $18,181,222.7 \mathrm{~m}$

The graphic 1 shows the percentage of ontime finish bulk and late finish bulk which fluctuates greatly. It is known that the average percentage of ontime finish bulk is $53.5 \%$ $(9,732,498.6 \mathrm{~m})$, while the average percentage of late finish bulk is $46.5 \%(8,448,724.1 \mathrm{~m})$. This certainly has bad consequences, such as customer claims against late orders so it will harm the company. Besides that, customer satisfaction to companies that cannot fulfill their orders accordingly to the due date. So Dedeh Kurniasih et al(2018)and Ari Soeti Yani (2019) said that production planning at the end of production has greatly impact to production effectiveness.

Furthermore, Mustajib (2010) mentioned that delivery times could be affected because of the company's efforts to meet the quality of components or products. Then these efforts will result in increased lead times which eventually cause the delivery delays. This is proven 
by the percentage of re-processing and replacement orders which received from PT. LPA like it shown in table 1. This likely happens due to a discrepancy in the order or quality requested, so the production control is needed. J. G. Wacker \& C. Sheu (2006) declared in their research that control procedures and planning procedures are the two of most important factors in improving the whole performance of manufacturing objectives. According to Sofjan Assauri (1980) the order control is the supervise of the production process that is carried out in ongoing product according to its order, both in terms of shape, type and quality.

Table 1. The Percentage of Late Re-Process and Replacement 2019

\begin{tabular}{ccccc}
\hline Order Type & R1 & R2 & R3 & Replacement \\
\hline LPA & $16.9 \%$ & $5.5 \%$ & $5.2 \%$ & $2.5 \%$ \\
\hline MAKLOON & $21.8 \%$ & $4.7 \%$ & $2.3 \%$ & $0.9 \%$ \\
\hline Grand Total & $20.4 \%$ & $4.9 \%$ & $4.1 \%$ & $2.0 \%$ \\
\hline
\end{tabular}

It is known from table 1.1 that the total finish productions for 2019 are $18,181,222.7 \mathrm{~m}$. Table 1 shows the total R1 which is $20.4 \%(3.424 .288 .0 \mathrm{~m}), \mathrm{R} 2$ is $4.9 \%(946.440 .0 \mathrm{~m}), \mathrm{R} 3$ is $4.1 \%(737.176 .0 \mathrm{~m})$ and Replacement is $2.0 \%$ ( $338,843.0 \mathrm{~m})$.

Re-process is an Order (Production) which is caused by an error in the production process/incompatibility of production results, so the order needs to be reprocessed which results in late finishing productions to the next order. That order did not follow the production process schedule so the capacity of machine will be used to correct the re-process of the order first. There are 3 types of re-process, namely R1 (Re-Process before Inspecting), R2 (ReProcess after Inspecting finished goods) and R3 (Re-Process after sending to the Finish goods warehouse). Replacement is a return order which is caused by the passage of finished goods products to customers with certain quantity, so the improvements are made from the initial production process and have an impact on late finish production order.

From these phenomena which are described above, it is found that several phenomena occur in the production effectiveness at PT. LPA includes the timeliness of completion of production orders and the relevance of order or quality compliance that has not been fulfilled so there would be re-processing or replacement orders. According to Ravianto (2014), the effectiveness could be interpreted as how well the work is done and the extent to which people produce output as expected. So if a job can be completed with precise planning of time, cost and quality, it can be said to be effective.

Production effectiveness should be based on the production planning process because the effectiveness is measured according to the ratio of actual output to planned output (target) of production orders. Okah Vincent Ph.D, Nduka Oyediya Ijedinma Ph.D, Ugwuegbu Charles Onyemachi M.sc (2018) described that production planning significantly affects the effectiveness of company's organization. A significant obstacle in the successful achievement of organizational results is the inability to plan properly before starting production. Dedeh Kurniasih, Tjutju Tarliah D, Pajar Supian Suri (2018) also stated that production planning and production time standards have an impact on production effectiveness. J. G. Wacker \& $\mathrm{C}$. 
Sheu (2006) explained that control procedures and planning procedures are the two most important factors in order to improve the whole performance of manufacturing objectives. Furthermore, The production effectiveness is also influenced by the need for raw materials, as in the research from I.R Octaviani et al (2019) who revealed that the production effectiveness did not yet achieved the level of effectiveness that caused by the control of raw material inventory which still not running well, such as when the orders should be made with the optimal amount of raw materials. And Dalgobind Mahto and Anjani Kumar (2008) defined that the production effectiveness is influenced by raw materials, operator competence that influenced by production planning.

\section{LITERATURE REVIEW}

\section{Manufacturing Textiles}

The definition of manufacturing according to Heizer et al (2005) is a production process through a machine to produce an item. While textiles according to Siregar et al (2011) is a material which comes from fiber and then processed to produce yarn then into fabric in the form of materials for making clothing and other products. Textiles are defined as materials derived from fibers. Generally, textile fibers could be categorized into two, namely natural and artificial fibers. Natural fibers are derived from natural fibers, which in general are fabrics made by natural fibers which are strong, dense, easily wrinkled and resistant to ironing. Natural fibers included cotton, hemp, linen/flax, wool and silk. While the artificial fibers are fibers which are made by humans and their molecules are arranged intentionally by humans. Man-made fibers have strong and friction-resistant properties. Examples of artificial fibers included rayon, nylon, polyester, spandex (Text Book Lucky print eternal, 2015). The fiber then undergoes a process, namely by processing it into yarn which is the result of spinning staple (short fiber) or filament (long fiber) that is commonly referred as the spinning process, then weaving (weaving) and finishing in the form of fabric that can be used as raw material for making clothes.

\section{Production Effectiveness}

Effectiveness according to Reider (2002) is the level of success of an organization to achieve goals and objectives. The Effectiveness focuses on results, achievements and benefits. The production process can be said to be effective if the production results are achieved and according to the targets or production plans that have been initially set. The production process can be said to be effective if the company can fulfill the planning and production targets that have been made punctual and used by optimal resources. The definition of effectiveness is more oriented towards achieving the number of production results from the production system by comparing the number of actual production results to the number of planned production results. According to Yamit on his book of Production and Operations Management, the effectiveness is an description towards the achievement of goals that could be view from quality and time. (Yamit, 2003). From these explanation and theory above, it can be said that the process and production results are effective because of the achievement of the goals that have been made through production planning, which in this 
case makes a strategy in planning orders received so they could be completed on time. Besides a good planning, raw material control is needed to ensure that those raw materials is available once they will be used in the production process. The production effectiveness is also determined by schedule control which can be seen from the planning when the order that carries out the production process until the order has been produced. After the production planning process, raw material control, schedule control, there is production control to ensure the production process can run smoothly and avoid any discrepancies in the production results with the requested order. Thus it effectiveness can be seen from the timeliness of completion the production from the planned time, suitability of orders and quality, suitability of design, color and type of raw materials and accuracy of costs incurred against the resulting costs.

\section{Production Planning}

Planning is one of the management functions. In this case, planning is determined by the efforts or actions which taken by the company's leaders to achieve company goals near the future. According to Wirasasmito (1999) who stated that production planning is a process of planning, selecting and Thinking how to produce the marketable products. Planning is also influenced by the number, type, size, style or quality of the product to be planned and produced and pricing is also included in product planning. From these explanation and theory above, it could be said that these production planning process starts from an order or customer request, including requests for raw materials used, designs, colors and the time of completion orders. Certainly the planning process will concern on the capacity of raw materials and machine capacity or production capacity per unit time. Then, a plan for completing the order could be made according to the company's ability to produce the order within a certain time in frame.

\section{Raw Material Control}

An Inventory is resource or raw material whose its existence needs waiting for further process. Further processes here means by the production activities that is found in manufacturing system or marketing activities aswell as in the distribution system (Bahagia, 2006). Astana (2007) were also explained that raw material planning is an concept in production management planning which discusses the right way to plan the needs of goods in the production process, so the goods needed will be available as its planned. Relates to these explanation and theory above, it can be said that the process of controlling raw materials is the process of providing raw materials that will be used for the production process. In this case, there are no issues which occurs due to unavailable raw materials when the production process started or run. To follow up on this, providing raw materials or extra inventory needs to be done by prevent additional raw material needs or delays in the arrival of raw materials. Nevertheless, the production order contracts with customers will assist in providing raw materials. Besides providing the right raw materials, the quality of raw materials is also important. The quality of raw materials could be find out in the smoothness of the production process and product results. 


\section{Schedule Control}

Schedule control is a tool where all company facilities are integrated into time units as it measures in other words determining when the product is ready (Reksohadiprodjo, 1997). Schedule control is the timing of the production process. Scheduling are includes the activities in allocating raw materials, facilities, equipment and labor for a production process activity as well as revealing the order in which operations are carried out so the start time and finish time of the production process can be estimated (Harjanto, 1997). From these explanation and theory above, it can be interpreted that the schedule control process is the process of finding or assessing the start time of production and its completion times in each production process flow. To discover the start time of the production process, certainly the main thing is to reveal the readiness of raw materials, the readiness of workforce and plan the order in a job Thus, it can be completed as its scheduled.

\section{Production Control}

Production control based on George R. Terry (1980) is the measuring implementation with objectives, discovering the causes of deviations and taking corrective actions where its necessary. Another definition according to Harsono (1984) said that this production control is not only to supervise the finished product, but also to supervise which starts from the initial process, namely raw material inventory process till finished goods and according to Cloude S. George (1991) production control is accelerating and supervising the production process through factory until the production process moves from one department to another in a systematic manner without any delays and minimum bottlenecks. From these explanation and theory, it can be interpreted if the production control process is the supervise on ongoing processed orders, And this carried out from the preparation process until its finished. Besides that, it aims to ensure the order is in accordance with the customer's request as well as monitor the work flow and ensure the smooth running process. Production control are also supervises and tests the quality or quality of the production, if there is orders which is not qualified with customer requests and its worsen quality or grade which is not good, corrective action to orders should be done immediately.

\section{Conceptual framework}

The conceptual framework in this research is to find out the affect of production planning, raw material control, schedule control and production control towards production effectiveness.

In a research that conducted by Dalgobind Mahto and Anjani Kumar (2008) were also said the production effectiveness is influenced by raw materials, operator skills which determine by production planning. According to eljko Mateljak and Damir Mihanović (2016) which stated that the more efficient operational planning will have a better impact on the effectiveness of the production process. Meanwhile, research conducted by Indah Rahadian Octaviani, Jaenudin, Dewi Taurusyanti (2019) stated that these effectiveness of production in the companies that've been studied did not yet reached the level of effectiveness. It caused by 
the control of raw material inventory that was still not going well, such as when to order and the amount of raw materials needed optimally, it can be said that the control of raw materials has an impact on the production effectiveness.

J. G. Wacker \& C. Sheu (2006) said in their research that the control procedures and planning procedures are the two most important factors in order to fixing the whole performance of manufacturing objectives. Research by Hassani et al (2019) is stated that integrates production planning and scheduling is very important to realize coherence between goals and capacity, production planning and scheduling are generally handled sequentially. Scheduling is highly depend on the production quantity which estimated at the production planning level. Wolosewicz (2008) mentioned that this estimated production time for a product is often different from its actual production time, which is a source of significant delays on delivery or work in progress for the company.

Referring to these phenomenon the production effectiveness will taking several causes according to previous research, it is greatly influenced by production planning (production planning), raw material requirements, scheduling and production control. The conceptual framework in this research could be seen as follows:

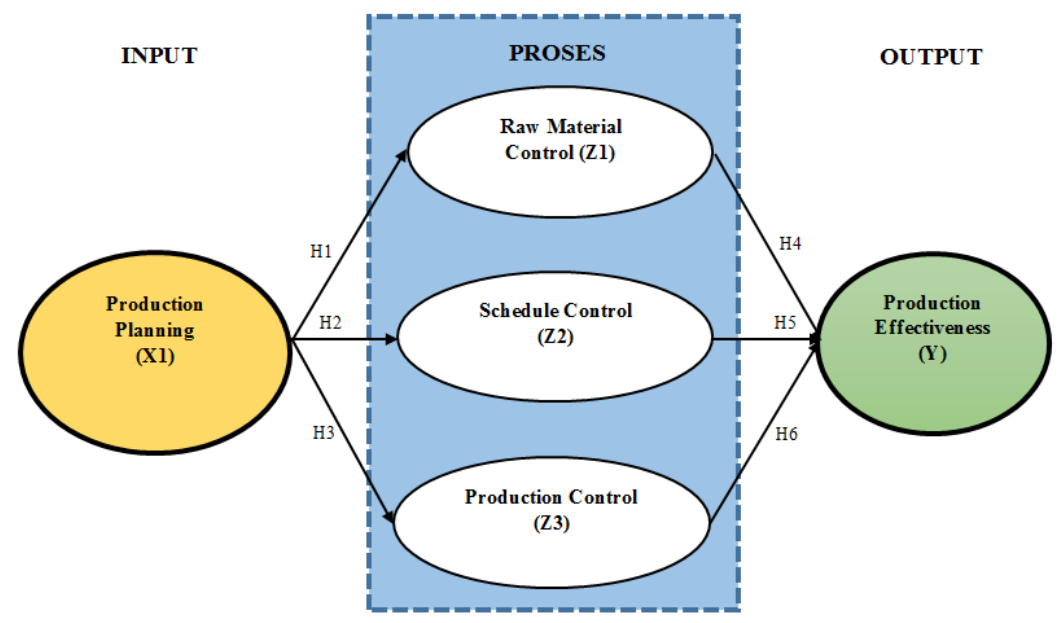

Figure 2. Conceptual Framework

The picture above was illustrated the correlation from several variables, which is production planning (X1) has a links with raw material control (Z1), schedule control (Z2) and production control ( $Z 3$ ) where this relations will be analyzed relates to strong and the direction of the relations. Then in the picture above were also described the correlations between variables (Z1), (Z2) and (Z3) to production effectiveness variable (Y1) and will be tested for its strength and direction of its influence in the analysis of variables.

According to the problem formulation and conceptual framework above, the hypothesis in this research that could be conveyed as follows:

H1: Production planning (X1) has an impact on raw material control (Z1).

H2: Production planning (X1) has an impact on schedule control (Z2). 
H3: Production planning (X1) has an impact on production control (Z3).

H4: Raw material control (Z1) has an impact on production effectiveness (Y).

H5: Schedule control (Z2) has an impact on production effectiveness (Y).

H6: Production control (Z3) has an impact on production effectiveness (Y)

\section{RESEARCH METHODS}

This research will describe the connection between variables through hypothesis test, namely those hypothesis examination based on the results from questionnaires which filled out by respondents and theories that have been created initially then the data that has been obtained is calculated by a quantitative method (Sugiyono, 2012). The research object was the employees of PT. LPA which is 65 and was obtained from managerial level employees in several divisions which directly related to research variables, such as Sales, Commerce Greige, PPC, Procurement and Production control/Capacity planning, Quality control finishing, Maintenance and Utility and Finishing production. Discovering the research sample through non-probability sampling, namely type of sample which is not selected at random. Whereas not all elements of the population have the same opportunity to be selected as samples. This research model used causality or the connection between variables. So to test the proposed hypothesis, the Partial Least Square-Structural Equation Modeling (PLS-SEM) analysis technique that used was operated through the SmartPLS program.

\section{FINDINGS AND DISCUSSION}

\section{Descriptive Statistics}

According to these variable description results, it shows that:

1) Production effectiveness variable (Y1), on timeliness indicator (Y1.1) were obtained data from respondent as many as 65\% (42 respondents) strongly agree, 28\% (18 respondents) agree, and $8 \%$ (5 respondents) are neutral. Statistically, this timeliness indicator (Y1.1) has the highest mean value, which is 4.57 and indicates that those respondents are agree if the timeliness of finishing production has an impact to production effectiveness.

2) Production Planning variable (X1) on the production capacity indicator (X1.5) were obtained data from respondents who strongly agreed 51\% (33 respondents) and agreed as many as $49 \%$ (32 respondents) and statistically it had the largest mean value among other indicators, namely 4.51 which means that production capacity has a major impact to production planning.

3) Raw material control variable (Z1) was determined by the ontime raw material indicator (Z1.3) with a percentage of 42\% (27 respondents) strongly agreeing and 55\% (36 respondents) agreeing, which also supported by statistical data with the largest mean value of 4, 37 meaning that the timeliness of the raw materials arrival has a large enough impact to raw materials control

4) According to the results of the questionnaire data is also shows that the schedule control variable (Z2), on the Allocate order indicator (Z2.2) has the greatest impact on schedule control variable with the percentage of respondents for strongly greeing 42\% (27 respondents) and respondents agreeing as many as 58\% (38 respondents) This proven by 
statistical data with a mean value of 4.42 which means that the majority of respondents were agreed by planning work order so then the production could be arranged systematically and will have an impact towards schedule control.

5) In the production control variable (Z3), on the order control indicator (Z3.1) has a large affects by respondents data with strongly agreeing 35\% (23 respondents), 60\% were agreeing (39 respondents) and 5\% (3 respondents) were neutral, supported by statistics with a mean value of 4.31 that also means if the majority of respondents agree that production control that carried out on the products which are made so the product would be based on customer expectation both regarding design and color, type and quality which affect the production control.

\section{Outer Model Evaluation}

The outer model test has purposes to see the value of validity and reliability of a model. The measurement of validity test were consists of convergent validity and discriminant validity. Convergent Validity means measuring the validity of reflexive indicators as a measure of variables which can be seen from the outer loading of each variable indicator. Measurements could be categorized as having convergent validity if the loading factor value $>0.7$ and the AVE value $>0.5$ (Jogiyanto, 2009). A measurement is categorized as having discriminant validity if it has a cross loading value of 0.7 (Jogiyanto, 2009).

\begin{tabular}{|c|c|c|c|c|c|c|c|}
\hline \multirow[t]{2}{*}{ Variable } & \multirow[t]{2}{*}{ Indicator } & \multicolumn{5}{|c|}{ Outer Loading } & \multirow[t]{2}{*}{ Information } \\
\hline & & X1 & $\mathrm{Zl}$ & Z2 & Z3 & Y1 & \\
\hline \multirow{6}{*}{$\begin{array}{l}\text { Production Planning } \\
\text { (X1) }\end{array}$} & X1.1 & 0.522 & 0 & 0 & 0 & 0 & Invalid \\
\hline & $\mathrm{X} 1.2$ & 0.764 & 0 & 0 & 0 & 0 & Valid \\
\hline & X1.3 & 0.773 & 0 & 0 & 0 & 0 & Valid \\
\hline & $\mathrm{Xl.4}$ & 0.849 & 0 & 0 & 0 & 0 & Valid \\
\hline & X1.5 & 0.775 & 0 & 0 & 0 & 0 & Valid \\
\hline & X1.6 & 0.809 & 0 & 0 & 0 & 0 & Valid \\
\hline \multirow{5}{*}{$\begin{array}{c}\text { Raw Material Con trol } \\
\text { (Z1) }\end{array}$} & Z1.1 & 0 & 0.782 & 0 & 0 & 0 & Valid \\
\hline & Z1.2 & 0 & 0.830 & 0 & 0 & 0 & Valid \\
\hline & Z1.3 & 0 & 0.803 & 0 & 0 & 0 & Valid \\
\hline & Z1.4 & 0 & 0.775 & 0 & 0 & 0 & Valid \\
\hline & Z1.5 & 0 & 0.675 & 0 & 0 & 0 & Invalid \\
\hline \multirow{4}{*}{$\begin{array}{l}\text { Schedule Control } \\
\text { (Z2) }\end{array}$} & Z2.1 & 0 & 0 & 0.877 & 0 & 0 & Valid \\
\hline & Z2.2 & 0 & 0 & 0.932 & 0 & 0 & Valid \\
\hline & Z2.3 & 0 & 0 & 0.800 & 0 & 0 & Valid \\
\hline & Z2.4 & 0 & 0 & 0.782 & 0 & 0 & Valid \\
\hline \multirow{4}{*}{$\begin{array}{c}\text { Production Control } \\
\text { (Z3) }\end{array}$} & Z3.1 & 0 & 0 & 0 & 0.878 & 0 & Valid \\
\hline & $\mathrm{Z} 3.2$ & 0 & 0 & 0 & 0.877 & 0 & Valid \\
\hline & Z3.3 & 0 & 0 & 0 & 0.854 & 0 & Valid \\
\hline & Z3.4 & 0 & 0 & 0 & 0.621 & 0 & Invalid \\
\hline \multirow{4}{*}{$\begin{array}{l}\text { Production Effectiveness } \\
\text { (Y1) }\end{array}$} & Y1.1 & 0 & 0 & 0 & 0 & 0.777 & Valid \\
\hline & Y1.2 & 0 & 0 & 0 & 0 & 0.851 & Valid \\
\hline & Y1.3 & 0 & 0 & 0 & 0 & 0.763 & Valid \\
\hline & Y1.4 & 0 & 0 & 0 & 0 & 0.745 & Valid \\
\hline
\end{tabular}

According to the table above, it is known that from this total of 23 indicators in this research, there are 3 indicators which have an outer loading value of $<0.7$, namely the $\mathrm{X} 1.1$, $\mathrm{Z} 1.5$, and Z3.4 indicators, meaning that this third indicator has a low correlation with construct or invalid. To overcome this, a re-test was carried out and was excluded these three indicators. Then the model was calculated again and gets a new outer loading value which can be seen in table 3 below: 
Table 3. Outer loading after revision

\begin{tabular}{|c|c|c|c|c|c|c|c|}
\hline \multirow[t]{2}{*}{ Variable } & \multirow[t]{2}{*}{ Indicator } & \multicolumn{5}{|c|}{ Outer Loading } & \multirow[t]{2}{*}{ Information } \\
\hline & & X1 & Z1 & $\mathrm{Z2}$ & Z3 & Y1 & \\
\hline \multirow{5}{*}{$\begin{array}{l}\text { Production Planning } \\
\text { (X1) }\end{array}$} & $\mathrm{X} 1.2$ & 0.776 & 0 & 0 & 0 & 0 & Valid \\
\hline & $\mathrm{X} 1.3$ & 0.790 & 0 & 0 & 0 & 0 & Valid \\
\hline & $\mathrm{X} 1.4$ & 0.857 & 0 & 0 & 0 & 0 & Valid \\
\hline & $\mathrm{X} 1.5$ & 0.770 & 0 & 0 & 0 & 0 & Valid \\
\hline & Xl.6 & 0.813 & 0 & 0 & 0 & 0 & Valid \\
\hline \multirow{4}{*}{$\begin{array}{l}\text { Raw Material Control } \\
\text { (Z1) }\end{array}$} & Z1.1 & 0 & 0.795 & 0 & 0 & 0 & Valid \\
\hline & Z1.2 & 0 & 0.834 & 0 & 0 & 0 & Valid \\
\hline & Z1.3 & 0 & 0.802 & 0 & 0 & 0 & Valid \\
\hline & Z1.4 & 0 & 0.819 & 0 & 0 & 0 & Valid \\
\hline \multirow{4}{*}{$\begin{array}{l}\text { Schedule Control } \\
\text { (Z2) }\end{array}$} & Z2.1 & 0 & 0 & 0.876 & 0 & 0 & Valid \\
\hline & Z2.2 & 0 & 0 & 0.932 & 0 & 0 & Valid \\
\hline & Z2.3 & 0 & 0 & 0.800 & 0 & 0 & Valid \\
\hline & Z2.4 & 0 & 0 & 0.782 & 0 & 0 & Valid \\
\hline \multirow{3}{*}{$\begin{array}{l}\text { Production Control } \\
\text { (Z3) }\end{array}$} & Z3.1 & 0 & 0 & 0 & 0.886 & 0 & Valid \\
\hline & Z3.2 & 0 & 0 & 0 & 0.897 & 0 & Valid \\
\hline & Z3.3 & 0 & 0 & 0 & 0.863 & 0 & Valid \\
\hline \multirow{4}{*}{$\begin{array}{l}\text { Production Effectiveness } \\
\text { (Y1) }\end{array}$} & Y1.1 & 0 & 0 & 0 & 0 & 0.775 & Valid \\
\hline & Y1.2 & 0 & 0 & 0 & 0 & 0.852 & Valid \\
\hline & Y1.3 & 0 & 0 & 0 & 0 & 0.761 & Valid \\
\hline & Y1.4 & 0 & 0 & 0 & 0 & 0.748 & Valid \\
\hline
\end{tabular}

From the table above, after Excluding the indicators X1.1, Z1.5, Z3.4, and it was found that from these 20 indicators in the research, all of them had an outer loading value $>0.7$, with values range from 0.748 to 0.932 , meaning that these 20 indicator has a good correlation with the construct or all indicators can said to be valid because they have met the indicator validity requirements.

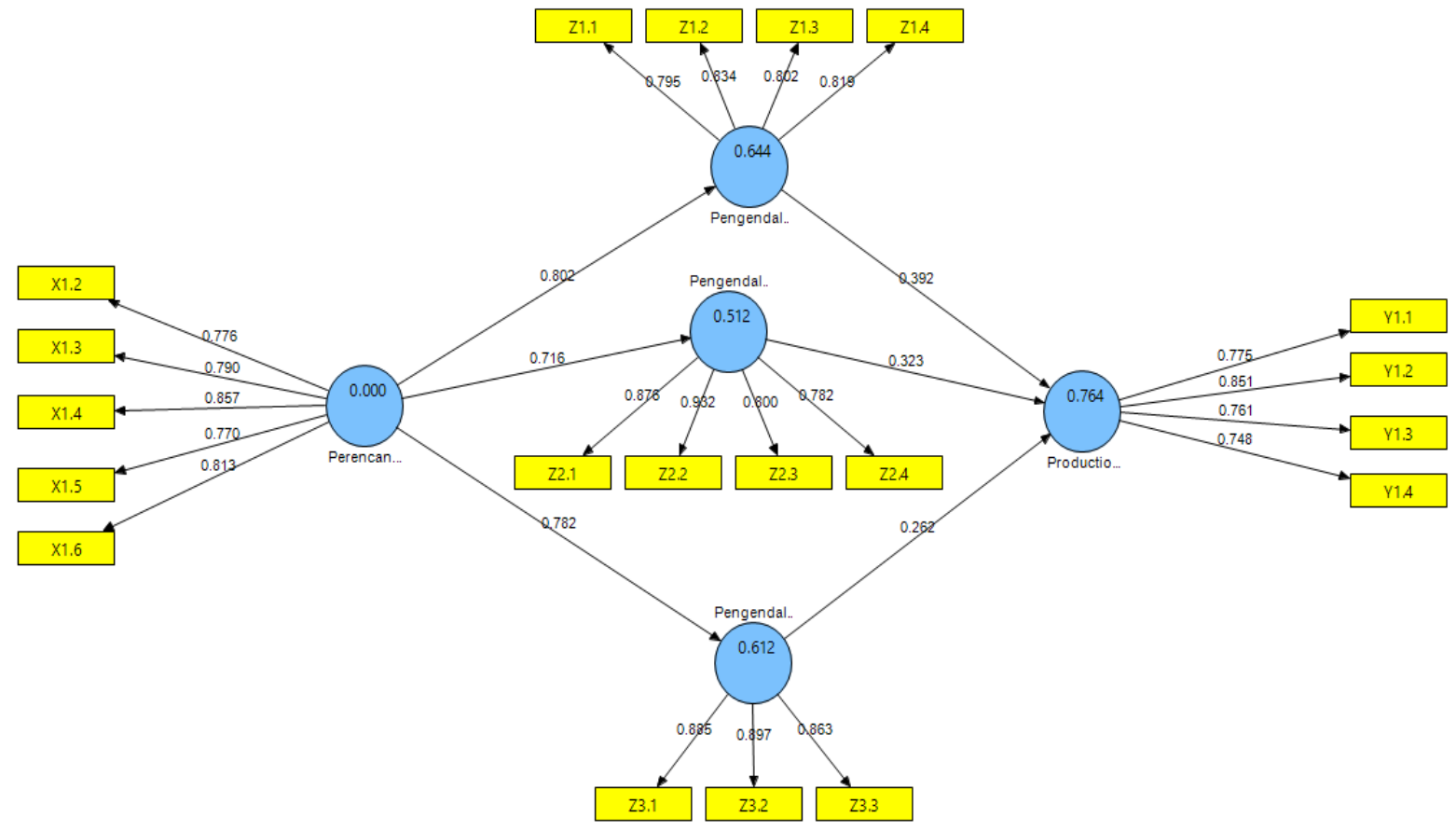


Figure 3. Final path diagram based on factor loading

A measurement is categorized as having discriminant validity if it has a cross loading value of 0.7 (Jogiyanto, 2009).

Table 4. Convergent validity after revision

\begin{tabular}{ccccccc} 
Variabel & Indicator & \multicolumn{5}{c}{ Cross Loading } \\
& & X1 & Z1 & Z2 & Z3 & Y1 \\
Production Planning & X1.2 & $\mathbf{0 . 7 7 6}$ & 0.602 & 0.482 & 0.662 & 0.606 \\
(X1) & X1.3 & $\mathbf{0 . 7 9 0}$ & 0.641 & 0.512 & 0.555 & 0.643 \\
& $\mathbf{X 1 . 4}$ & $\mathbf{0 . 8 5 7}$ & 0.705 & 0.668 & 0.629 & 0.728 \\
& $\mathbf{X 1 . 5}$ & $\mathbf{0 . 7 7 0}$ & 0.544 & 0.663 & 0.691 & 0.648 \\
& X1.6 & $\mathbf{0 . 8 1 3}$ & 0.721 & 0.526 & 0.597 & 0.650 \\
Raw Material Control & $\mathbf{Z 1 . 1}$ & 0.586 & $\mathbf{0 . 7 9 5}$ & 0.507 & 0.510 & 0.648 \\
(Z1) & $\mathbf{Z 1 . 2}$ & 0.673 & $\mathbf{0 . 8 3 4}$ & 0.563 & 0.609 & 0.646 \\
& $\mathbf{Z 1 . 3}$ & 0.645 & $\mathbf{0 . 8 0 2}$ & 0.455 & 0.590 & 0.590 \\
Schedule Control & $\mathbf{Z 1 . 4}$ & 0.698 & $\mathbf{0 . 8 1 9}$ & 0.585 & 0.698 & 0.702 \\
(Z2) & $\mathbf{Z 2 . 1}$ & 0.652 & 0.603 & $\mathbf{0 . 8 7 6}$ & 0.684 & 0.658 \\
& $\mathbf{Z 2 . 2}$ & 0.652 & 0.643 & $\mathbf{0 . 9 3 2}$ & 0.635 & 0.705 \\
& $\mathbf{Z 2 . 3}$ & 0.597 & 0.520 & $\mathbf{0 . 8 0 0}$ & 0.536 & 0.671 \\
Production Control & $\mathbf{Z 2 . 4}$ & 0.521 & 0.429 & $\mathbf{0 . 7 8 2}$ & 0.534 & 0.548 \\
(Z3) & $\mathbf{Z 3 . 1}$ & 0.738 & 0.653 & 0.586 & $\mathbf{0 . 8 8 6}$ & 0.699 \\
& $\mathbf{Z 3 . 2}$ & 0.687 & 0.683 & 0.635 & $\mathbf{0 . 8 9 7}$ & 0.676 \\
Production Effectiveness & $\mathbf{Z 3 . 3}$ & 0.642 & 0.632 & 0.649 & $\mathbf{0 . 8 6 3}$ & 0.693 \\
(Y1) & Y1.1 & 0.492 & 0.517 & 0.514 & 0.488 & $\mathbf{0 . 7 7 5}$ \\
& $\mathbf{Y 1 . 2}$ & 0.738 & 0.640 & 0.692 & 0.688 & $\mathbf{0 . 8 5 2}$ \\
& $\mathbf{Y 1 . 3}$ & 0.758 & 0.653 & 0.567 & 0.572 & $\mathbf{0 . 7 6 1}$ \\
& Y1.4 & 0.555 & 0.672 & 0.602 & 0.675 & $\mathbf{0 . 7 4 8}$
\end{tabular}

According to the table above, it can be seen that the cross loading value which has the highest value in the variables it forms compared to the values in other variables with a cross loading value $>0.7$ which ranges from 0.748 to 0.932 . So it can be concluded that all indicators have met the criteria and can be qualified for further analysis.

Discriminant validity could be seen by looking at the average variant extracted (AVE) value for each indicator, the value must be $>0.5$ for a good model. From the table it can be seen that all indicators used for variables were declared valid because the AVE value is above 0.5 . Thus, it can be defined that each variable has good discriminant validity.

Table 5. Average Variance Extracted (AVE) Value

Raw Material Control
Schedule Control
Production Control
Production Planning
Production Effectiven ess

Average $V$ ariance Extracted (AVE)

0.660

0.722

0.778

0.643

0.616

Table 6. Composite Reliability \& Cronbach's Alpha Value

\begin{tabular}{lccc}
\multicolumn{1}{c}{ Variable } & Cronbachs Alpha & Composite Reliability & $\begin{array}{c}\text { Information } \\
\text { Reliable }\end{array}$ \\
Raw Material Control & 0.829 & 0.886 & Reliable \\
Schedule Control & 0.870 & 0.912 & Reliable \\
Production Planning & 0.861 & 0.900 & Reliable
\end{tabular}


A latent variable can be said have good reliability if the composite reliability value was greater than 0.7 (Sarwono \& Narimawati 2015). A variable could be declared reliable or fulfills the cronbach's alpha if it has a cronbach alpha value $>0.7$ (Sarwono and Narimawati 2015). According to the table above, it can be seen that the composite reliability value for all research variables $>0.6$ with values range from 0.865 to 0.913 and Cronbach's alpha value $>$ 0.7 with values ranging from 0.792 to 0.870 . These results was indicate that all variables have met the criteria so it can be interpreted that all variables has a good level of reliability.

\section{Inner Model Evaluation}

The Evaluation of Coefficient of Determination $\left(\mathrm{R}^{2}\right)$ is a tool to display how much affect or influence that independent variable has on dependent variable. The R-Square value in this model could be seen from the table below.

\begin{tabular}{lc}
\multicolumn{2}{c}{ Table 7. R-Square Value } \\
Variable & R Square \\
Raw Material Control & 0.644 \\
Schedule Control & 0.512 \\
Production Planning & 0.612 \\
Production Effectiven ess & 0.764
\end{tabular}

From the Project Performance response variable (Y), the R-Square value is 0.764 . This describe that the large percentage of predictor variables, namely Raw Material Control, Schedule Control and Production Control could tell the Production Effectiveness of $76.4 \%$. While the rest, which is $23.6 \%(100 \%-76.4 \%=23.6 \%)$ was determined by other factors outside this research model between Raw Material Control, Schedule Control, and Production Control towards Production Effectiveness.

\section{Hypothesis Test}

\begin{tabular}{|c|c|c|c|c|}
\hline Hypothesis & Relationship & Path Coefficient & T Statistics & Information \\
\hline $\mathrm{Hl}$ & $\begin{array}{l}\text { Production Planning -> } \\
\text { Raw Material Control }\end{array}$ & 0.802 & 19.059 & $\begin{array}{l}\text { Has positive and } \\
\text { significant affect }\end{array}$ \\
\hline H2 & $\begin{array}{l}\text { Production Planning -> } \\
\text { Schedule Control }\end{array}$ & 0.716 & 10.642 & $\begin{array}{l}\text { Has positive and } \\
\text { significant affect }\end{array}$ \\
\hline H3 & $\begin{array}{l}\text { Production Planning -> } \\
\text { Production Control }\end{array}$ & 0.782 & 15.217 & $\begin{array}{l}\text { Has positive and } \\
\text { significant affect }\end{array}$ \\
\hline H4 & $\begin{array}{l}\text { Raw Material Control -> } \\
\text { Production Effectiveness }\end{array}$ & 0.392 & 2.439 & $\begin{array}{l}\text { Has positive and } \\
\text { significant affect }\end{array}$ \\
\hline H5 & $\begin{array}{l}\text { Schedule Control -> } \\
\text { Production Effectiveness }\end{array}$ & 0.323 & 3.043 & $\begin{array}{l}\text { Has positive and } \\
\text { significant affect }\end{array}$ \\
\hline H6 & $\begin{array}{l}\text { Production Control -> } \\
\text { Production Effectiveness }\end{array}$ & 0.262 & 2.058 & $\begin{array}{l}\text { Has positive and } \\
\text { significant affect }\end{array}$ \\
\hline
\end{tabular}

\section{The Impact of Production Planning on Raw Material Control}

Path coefficient value is positive at 0.802 and also known that T-Statistics value of (19.059) $>\mathrm{T}$ table (1.998) then the hypothesis $\mathrm{H} 0$ was rejected and $\mathrm{H} 1$ was accepted. 
Meaning that there is a significant positive impact of Production Planning on Raw Material Control. This describe that the higher value of Production Planning, Then the Raw Materials control will also higher or increase and conversely if the value of Production Planning is lower, then the Raw Materials control will be lower or decrease aswell. In the correlation between indicators can be explained that the largest correlation value between the production planning variable (X1) and the raw material control variable (Z1) is found in the correlation between the order completion plan indicator (X1.6) and the safety stock indicator (Z1.2), namely with a correlation coefficient value of 0.644 which means that it includes a high correlation, it can be said that production planning has a high correlation with the availability of raw materials. This has a direct influence on the direction of its influence, namely the higher the availability of raw materials, the more precise the planning of the finished order. For example, if the raw materials needed are available in sufficient quantities such as yarn, dyes and chemicals, the planning for the completion of the order will be right at the specified time because if the raw materials are not available, there will be a delay in waiting for the arrival of the raw materials so that the production planning will change well in terms of time and planning that is not achieved.

\section{The Impact of Production Planning on Schedule Control}

The path coefficient value is positive at 0.716. was also known, the T-Statistics value $(10.642)>\mathrm{T}$ table (1.998) then the hypothesis $\mathrm{H} 0$ was rejected and H1 was accepted. Meaning that there is a significant positive impact of Production Planning on Schedule Control. This will explains that the higher the value of Production Planning, the Schedule Control will also be higher or increase or conversely if the value of Production Planning is lower, then the Schedule Control will also be lower or decreased. When we viewed in terms of the correlation between indicators on the production planning variable (X1) and schedule control variable (Z2), there is an indicator with the highest correlation coefficient value, namely between the request delivery order indicator (X1.4) and time production indicator (Z2.1). which is equal to 0.638 . This correlation coefficient value were included in the high correlation category according to Sugiono (2017) because the coefficient value is in the range $0.60-0.799$. The influence between production planning variables and schedule control is that the higher the demand for delivery orders, the greater the production time required, so it can be said that the better the production planning, the better the schedule control will increase. As a real example, when a customer submits a request for a high number of orders, a larger production time is required, therefore the control of the production schedule must be further improved and regulated so that orders can be completed on demand

\section{The Impact of Production Planning on Production Control}

The path coefficient value is positive at 0.783 . And also known, that T-Statistics value of T-Statistics (15.217) > T table (1.998) then the hypothesis H0 was rejected and H1 was accepted. Meaning that there is a significant positive impact of Production Planning on Production Control. This explains that the higher value of Production Planning, then the higher Production Control will be. Conversely if the value of Production Planning is lower 
then Production Control will be lower or decreased aswell. Acording to the correlation between production planning variables (X1) and production control (Z3) can be viewed based on the correlation coefficient values between these indicators. The highest correlation coefficient value is between the production capacity indicator (X1.5) and the quality control indicator (Z3.3) which is 0.653 . The correlation coefficient value of 0.653 according to Sugiono (2017) were included in the high correlation category because the coefficient value is in the range of $0.60-0.799$. This means that the production planning variable has a direct influence on the production control variable, with the direction of influence, namely the higher the production planning, the higher the production control, the higher the production capacity planning, the higher the quality control. As a real example, when the production capacity is well planned in the sense that it did not exceed the limits of each production machine, quality control will increase with reduced production defects of the fabric produced.

\section{The Impact of Raw Material Control on Production Effectiveness}

The path coefficient value is positive at 0.392 . It is also known that the value of $\mathrm{T}$ Statistics (2.439) > T table (1.998) then the hypothesis H0 was rejected and H1 is accepted. Meaning that there is a significant positive impact from Raw Material Control on Production Effectiveness. This explains that the higher the value of Raw Material Control, the Production Effectiveness will also be higher or increase. Vice versa if the value of Raw Material Control is lower, the Production Effectiveness will also be lower or decrease. The impact of raw material control variable on production effectiveness can also be seen from the value of the correlation coefficient between the dimension variables. The largest correlation coefficient was obtained between the Order Conformity and Quality indicators (Y1.2) against the Quality of Raw Material indicators with a coefficient value of 0.620 . This coefficient value is included in the category of high correlation, meaning that the raw material control variable has a high correlation and has a direct effect towards the production effectiveness . The direction of the effect is that the higher the control of raw materials, the higher the production effectiveness will be . It also could be said that the higher the quality of raw materials, the higher the suitability of orders and quality. As a real example, when the quality of the raw materials for making fabrics such as good yarn quality, good dyes or chemicals with good quality, then production will be more effective because order conformity and its product quality are achieved, efficient, do not waste raw materials and production costs because there are no orders which is must be returned or repeated

\section{The Impact of Schedule Control on Production Effectiveness}

The path coefficient value is positive at 0.323 . It is known that the value of T-Statistics (3.043) $>\mathrm{T}$ table (1.998) then the hypothesis $\mathrm{H} 0$ was rejected and H1 was accepted. Meaning that there is a significant positive impact from Schedule Control to Production Effectiveness. This explains that the higher the Schedule Control value, then the Production Effectiveness will be higher or increase aswell. Likewise, if the Schedule Control value is lower, then the Production Effectiveness will be lower or decreased. The correlation coefficient results which obtained between the dimensions of the schedule control variable on production effectiveness 
are shown in table 4.13, that the highest correlation coefficient between the Allocate Order indicator (Z2.2) and the Order Conformity and Quality indicator (Y1.2) was 0.654. Meaning that schedule control has a high correlation with direct production effectiveness. The direction of the impact would be the more control schedule, the higher the production effectiveness. The better the planning of the work sequence so the production would be arranged systematically, the higher the order suitability and its quality of the production At PT.LPA, if the production schedule is properly arranged in a systematic order, then the fabric production will be based on the order requirement with the best quality, this can minimize errors, avoid additional production costs because there is no re-production, so the effective production is achieved.

\section{The Impact of Production Control on Production Effectiveness}

The path coefficient value is positive at 0.262 . It is known that the value of T-Statistics (2.058) $>\mathrm{T}$ table (1.998) then the hypothesis $\mathrm{H} 0$ was rejected and $\mathrm{H} 1$ was accepted. Meaning that there is a significant positive impact from Production Control to Production Effectiveness. It explains that the higher value of Production Control, the higher Production Effectiveness will be. And conversely if the value of Production Control is lower likewise with the Production Effectiveness. It describes that there is an impact from production control to production effectiveness when it viewed from the correlation coefficient between the dimensional variables. The highest correlation coefficient value was found in the correlations between the Quality Control indicator (Z3.3) to the order comformity indicator and quality (Y1.2) which is 0.670. Based on Sugiono (2017) this value were included in the high correlation category because the coefficient value is in the range of $0.60-0.799$. So the direct production control variable has a high correlation impact on the production effectiveness. The higher the production control, the higher the production effectiveness. The better the quality control during production, the higher the order comformity and product quality. For example, during the production process quality is always be maintained at every stages of production including material and tools conditions during production which could affect the results including operating conditions such as temperature control, pressure and other physical conditions, the product obtained will be according to the request with best quality which according to expectations so the production effectiveness would achieved because it will minimizes the order repairs, there are no additional costs and certainly will saves the time.

\section{CONCLUSION AND SUGGESTION}

Production planning has a significant and positive impact on raw material control, schedule control and production control. The statement explains that the higher the production planning value, the higher impact value from raw material control, schedule control and production control will be. It is also related if the influence value of production planning is low then the impact value from raw material control, schedule control and production control will be low aswell

Raw material control has a significant and positive impact on production effectiveness with a path coefficient value of 0.392 , this explains that the higher raw material control value, 
the higher production effectiveness will be . Schedule control has a significant and positive impact on production effectiveness with a path coefficient value of 0.323 . This explains that the higher schedule control value, likewise with production effectiveness. Production control has a significant and positive impact on production effectiveness with a path coefficient value of 0.262 . This explains that the higher the production control value, would be higher the production effectiveness.

Production effectiveness could be increased by improving indicators of timeliness, order comfromity and quality, design suitability, color and type of raw materials and cost accuracy. Those above will be achieved by performed a proper production planning, starting from controlling the raw materials used, controlling the production schedule and controlling the production process or supervise it to minimize the occurrence of errors which made in both of process and results.

\section{REFERENCES}

Astana, I. Y. N. (2007). Perencanaan Persediaan Bahan Baku Berdasarkan Metode MRP (Material Requirement Planning). Jurnal Ilmiah Teknik Sipil, 11(2).

Bahagia, S. N. (2006). Sistem Inventori (edisi 1). Bandung: Insitut Teknologi Bandung.

DP, A. H. (2020). Improvement of Project Performance Through Planning, Team Capability, Procurement Of Materials, And Work Scope Case Study In The MRO Project. International Journal of Research in Commerce and Management Studies, 2(3).

Gaspersz, V. (2012). All In One: Production and Inventori Management, Edisi 8. Bogor: Vinchristo Publication.

Heizer, J., \& Barry, R. (2005). Operations Management. Jakarta: Salemba Empat.

Jogiyanto, H. M. (2011). Metodologi Penelitian Bisnis Edisi Keempat. BPFE. Yogyakarta.

Kurniasih, D., Tarliah, D. T., \& Suri, P. S. (2015). Perencanaan Kapasitas Produksi Untuk Box Kemasan Aluminium Foill. Bandung: Universitas Pasundan.

Mateljak, Ž., \& Mihanović, D. (2016). Operational planning level of development in production enterprises in the machine building industry and its impact on the effectiveness of production. Economic research-Ekonomska istraživanja, 29(1), 325342.

Octaviani, I. R., Jaenudin, J., \& Taurusyanti, D. (2019). ANALISIS PENGENDALIAN PERSEDIAAN BAHAN BAKU DALAM MENINGKATKAN EFEKTIVITAS PRODUKSI PADA PT. BATARA INDAH. Jurnal Online Mahasiswa (JOM) Bidang Manajemen, 4(4).

Ravianto J. (2014). Produktivitas dan Pengukuran, Jakarta: Binaman Aksara, Serikat Perusahaan Pers.

Siregar, Y., \& Eriningsih, R. (2011). Kain Rajut Kapas Dengan Sisipan Benang Karbon Untuk Keperluan Tekstil Teknik Tahan Api. Arena Tekstil, 26(2).

Terry, G., \& Rue, L. W. (1988). Dasar-Dasar Manajemen, alih bahasa, G.A. Ticoalu, Jakarta: Bina Aksara. 
Wacker, J. G., \& Sheu, C. (2006). Effectiveness of manufacturing planning and controlsystems on manufacturing competitiveness: evidence from global manufacturing data. International Journal of Production Research, 44(5), 1015-1036.

Wolosewicz, C. (2008). Integrated approach to planning and production scheduling (Doctoral dissertation, Doctoral thesis at the national higher school of mines. Saint Etienne, Saint Etienne, France.

Yamit, Z. (2003). Manajemen Produksi Dan Operasi, Edisi Kedua. Yogyakarta: FE UII.

Yani, A. S. (2017). Pengaruh Perencanaan Produksi dan Standar Waktu Produksi Terhadap Efektivitas Produksi Pada Umkm Haqqi Collection Cleungsi-Bogor. Sumber, 3, 3900. 